\title{
Alcohol consumption, Quality of Life and Brief Intervention among Nursing university students
}

\author{
Consumo de álcool, qualidade de vida, Intervenção Breve entre universitários de Enfermagem \\ Consumo de alcohol, calidad de vida, Intervención Breve entre universitarios de Enfermería
}

\section{Wanda Cristina Sawicki', Dulce Aparecida Barbosa", Dayana Souza Fram", Angélica Gonçalves Silva Belasco'}

'Universidade Federal de São Paulo, Escola Paulista de Enfermagem, Postgraduate Program in Health Sciences. São Paulo, Brazil. "Universidade Federal de São Paulo, Escola Paulista de Enfermagem, Departament of Nursing. São Paulo, Brazil.

\section{How to cite this article:}

Sawicki WC, Barbosa DA, Fram DS, Belasco AGS. Alcohol consumption, Quality of Life and Brief Intervention among Nursing university students. Rev Bras Enferm [Internet]. 2018;71(Suppl 1):505-12. [Thematic Issue: Contributions and challenges of nursing practices in collective health] DOI: http://dx.doi.org/10.1590/0034-7167-2017-0692

\section{Submission: 13-06-2017 Approval: 08-17-2017}

\section{ABSTRACT}

Objective: To evaluate nursing university students' alcohol consumption patterns, Brief Intervention and Quality of Life (QoL). Method: This is a prospective and longitudinal study containing sociodemographic, economic information concerning alcoholic beverages, BI and QoL evaluation among 281 nursing university students. Since surveys have been applied, seminars have been given and consumption patterns have been discussed, an educational material was delivered after university students' revaluation and BI reinforcement. Descriptive and analytical statistics have been conducted. Results: $90 \%$ of the students have already consumed alcohol and $20.6 \%$ that consumed for the first time and abused alcohol were minors. After the implementation of BI, the alcohol consumption has decreased among university students. Besides the vitality, generate state of health, and emotional aspects have decreased, mental health was substantially low among the students that used to drink. Conclusion: BI contributes to decrease alcoholic beverages consumption and promotes health.

Descriptors: Alcohol Consumption; Students; Nursing; Health Promotion; Quality of Life.

\section{RESUMO}

Objetivos: Avaliar o padrão de consumo de álcool, o impacto da Intervenção Breve (IB) e a qualidade de vida (QV) de universitários de Enfermagem. Método: Estudo prospectivo longitudinal realizado com informações sociodemográficas, econômicas, ingesta de bebidas alcoólicas, IB e avaliação da QV de 281 universitários de Enfermagem. Aplicados questionários; realizada palestra e discutido sobre padrão de consumo, entregue material informativo após reavaliação dos universitários e reforço da IB. Realizada estatística descritiva e analítica. Resultados: Já ingeriram álcool 90\% dos universitários e 20,6\% faziam uso abusivo/nocivo associado significativamente à menor idade do primeiro uso. Após IB, diminuiu significantemente o consumo de álcool entre universitários. Vitalidade, estado geral de saúde e aspectos emocionais dos universitários estavam diminuídos e a saúde mental significativamente menor entre universitários que bebiam. Conclusão: A IB contribuiu com a diminuição do consumo de bebidas alcoólicas e na promoção da saúde.

Descritores: Consumo de Bebidas Alcoólicas; Estudantes; Enfermagem; Promoção da Saúde; Qualidade de Vida.

\section{RESUMEN}

Objetivos: Evaluar el patrón de consumo de alcohol, el impacto de la Intervención Breve (IB) y la calidad de vida (CV) de universitarios de Enfermería. Método: Estudio prospectivo longitudinal realizado con informaciones sociodemográficas y económicas, la ingesta de bebidas alcohólicas, la IB y la evaluación de la CV de 281 universitarios de Enfermería. Se han aplicado cuestionarios, realizado una conferencia y debatido el patrón de consumo de alcohol. Se entregó material informativo tras la reevaluación de los universitarios y refuerzo de la IB. Se realizó una estadística descriptiva y analítica. Resultados: Ya ingirieron alcohol el $90 \%$ de los universitarios y el 20,6\% lo hacían uso abusivo/ nocivo, asociado significativamente a la más corta edad del primer uso. Tras la IB, el consumo del alcohol disminuyó notablemente entre los universitarios. La vitalidad, el estado general de salud y los aspectos emocionales de los universitarios estaban disminuidos y la salud mental significativamente más baja entre los que bebían. Conclusión: La IB ha contribuido con la disminución del consumo de bebidas alcohólicas y la promoción de la salud.

Descriptores: Consumo de Bebidas Alcohólicas; Estudiantes; Enfermería; Promoción de la Salud; Calidad de Vida.

\section{CORRESPONDING AUTHOR Wanda Cristina Sawicki E-mail: sawicki@unifesp.br}




\section{INTRODUCTION}

Alcohol is the most consumed psychoactive substance worldwide $^{(1)}$; its rate of consumption and prevalence among Brazilians have grown ${ }^{(2-3)}$, and those who experience changes and, experience social life, distance themselves from the family, spend full time in the university and are free and independent to make their own decisions. This is a critical and vulnerable stage for commencement and maintenance of alcohol consumption in which can be more frequent and intense when compared to general consumption of population ${ }^{(3-4)}$.

Drinking to excess grows disease rates, causes social and psycho problems, urban violence and interferes with quality of life and expectancy. As they focus on education, motivation and encourage reflection, therapeutical approaches as Brief Intervention $(\mathrm{BI})^{(5)}$ can increase life expectancy, reduce social costs, and health care maintenance ${ }^{(6)}$. BI technique application structure is composed by health education actions for individuals, identified as consumers of psychoactive substances (PAS) such as alcohol, providing them advice that aims at promoting new behaviors in the face of reduction of consumption through personal responsibility and treatment for harmful/dependence of $\mathrm{PAS}^{(7)}$. A systemic review about $\mathrm{BI}$ effectiveness in the alcohol abuse has suggested that it must be incorporated into the public policies as a strategy to deal with abusive consumption and prevention of chemical dependence ${ }^{(8)}$.

A study held with university students from different courses has evaluated alcohol consumption and, after a deep analysis of consumption pattern, it has shown that preventive consultancy can aware consciousness of people and generate a positive response to reduce alcohol consumption and its harmful effects ${ }^{(9)}$.

Drinking to excess modifies the quality of life (QoL) which is famous for being subjective, multidimensional, cultural and not constrained to health conditions. Quality of life related to health makes reference to general conditions of a public, group or an individual and can be described as a psychological and multidimensional construct that encompasses physical, psycho, social, functional, spiritual environmental aspects, and impacts on health ${ }^{(10)}$.

\section{OBJECTIVE}

This study aimed at evaluating the alcohol consumption pattern, Brief Intervention (BI) effectiveness and quality of life (QoL) of nursing university students.

\section{METHOD}

\section{Ethical aspects}

This research was approved by the Research Ethics Committee of Universidade Federal de São Paulo (UNIFESP). Participants have signed the Free and Clarified Consent Form and they were instructed about the study's aims and stages.

\section{Design, place of study and period}

This is a prospective longitudinal study held in the classrooms of Escola Paulista de Enfermagem (EPE) with nursing
University students from Universidade Federal de São Paulo (UNIFESP), between March, 2015 and September, 2016.

\section{Population and sample}

Only 281 (92.43\%) accepted participating in the study and $23(7.57 \%)$ refused so that they were disqualified, among 304 university students enrolled in the four grades. A coordination course and faculty's approval was requested to use part of the class to hold the research.

\section{Study protocol}

The study was carried out in four stages: in the first one, sociodemographic, economic data (CRITERION BRASIL, 2013) (11), information on alcohol consumption were collected using the Alcohol Use Disorders Identification Test (AUDIT) of Medical Outcomes Studies 36-items short-form (SF-36). The AUDIT was elaborated by World Health Organization (WHO); has been translated and authenticated into Brazilian Portuguese; it is selfreport, evaluate and classify consumption pattern from the sum of 10 questions in which each one has a value ranging between 0 and 40 points ${ }^{(12)}$. A low risk corresponds between 0 and 7 points; risky use between 9 and 15; harmful use between 16 and 19 and possible addiction, between 20 and 40 . We follow the recommended and used classification by WHO and other researchers ${ }^{(13)}$, that considers abstinence or low risk when the score is lower than 8; risky or harmful consumption or possible addiction when the score equals 8 or it is higher. The SF-36 generic instrument was translated and validated in Brazil(14), and evaluates QoL, contains 36 items, distributed in 8 domains: functional capacity, physical and emotional aspects, pain, general state of health, vitality, social aspects and mental health. Each domain receives a score ranging from zero: worse, and one hundred: better QoL.

In the second stage (two weeks after the first one) the BI was applied, which included the consolidated results of the AUDIT for university students from each grade, followed by a seminar about "Alcohol Consumption and its Consequences" discussing epidemiological aspects; consumption levels and consequence of abuse, alcohol abuse and addiction; alcohol effects, metabolism and action; delivery of "Alcoholic beverages: Ethyl Alcohol, Ethanol" brochures ${ }^{(15)}$ and booklet referral "Drugs: Alcohol and Young People Booklet"(16) to each grade's email address.

In the third stage (three months after the second one) 272 university students took part of the third stage (nine students left the course). Applied AUDIT, SF-36 and BI evaluation previously performed.

In the fourth stage (one year after the third one) 42 university students were called because they still presented risky/harmful/ probable addiction consumption, 36 accepted the invitation and 5 refused it. An individual feedback of results of AUDIT from the third stage has been conducted and oriented a new reading of the booklet. After two weeks, they filled out the SF-36 and AUDIT forms.

\section{Data analysis}

The data were stored in Excel bank (2010). Statistical analysis employed the Statistical Package for Social Sciences (SPSS), version 19, the descriptive analysis of quantitative variables covered absolute and relative frequency and the quantitative, position 
measures. To verify the relationship between variables and between steps, we used Anova, McNemar, GEE/Q de Cochran, R Likelihood, Chi-Square and Spearmam. The level of significance was $5 \%(p \leq 0.05)$.

\section{RESULTS}

Table 1 shows sociodemographic and economic variables of nursing university students of UNIFESP that took part of the course in 2015.

Table 1 - Sociodemographic and economic characteristics of nursing students, Escola Paulista de Enfermagem-Universidade Federal de São Paulo, São Paulo State, Brazil, $2015(\mathrm{~N}=281)$

\begin{tabular}{|c|c|c|}
\hline Characteristics & $\mathbf{n}$ & $\%$ \\
\hline Age* & 21.44 & $(3.44)$ \\
\hline \multicolumn{3}{|l|}{ Gender } \\
\hline Female & 255 & 90.7 \\
\hline Male & 26 & 9.3 \\
\hline \multicolumn{3}{|l|}{ Skin color } \\
\hline White & 196 & 69.8 \\
\hline Brown & 47 & 16.7 \\
\hline Yellow & 29 & 10.3 \\
\hline Black & 9 & 3.2 \\
\hline \multicolumn{3}{|l|}{ Religion } \\
\hline Catholic & 120 & 42.7 \\
\hline Evangelical & 47 & 16.7 \\
\hline None & 47 & 16.7 \\
\hline Spiritist & 43 & 15.3 \\
\hline Atheist & 10 & 3.6 \\
\hline Other & 14 & 5 \\
\hline \multicolumn{3}{|l|}{ Grade in course } \\
\hline First & 100 & 35.6 \\
\hline Second & 50 & 17.8 \\
\hline Third & 78 & 27.8 \\
\hline Forth & 53 & 18.9 \\
\hline \multicolumn{3}{|l|}{ Who they live with } \\
\hline Family & 233 & 82.9 \\
\hline Friend & 32 & 11.4 \\
\hline Alone & 11 & 3.9 \\
\hline Boarding house & 5 & 1.8 \\
\hline \multicolumn{3}{|l|}{ Employment } \\
\hline Yes & 30 & 11 \\
\hline No & 251 & 89 \\
\hline \multicolumn{3}{|l|}{ Activity performed $* *$} \\
\hline Nursing intern & 19 & 63.3 \\
\hline Nursing assistant & 5 & 16.7 \\
\hline Other & 6 & 20 \\
\hline Individual income (reais) $* * / * * *$ & 816 & $(400-7000)$ \\
\hline \multicolumn{3}{|l|}{ Family income (reais/BC) } \\
\hline 11037 & 46 & 16.4 \\
\hline $6006-3118$ & 186 & 66.1 \\
\hline $1865-1277$ & 42 & 15 \\
\hline 895 & 7 & 2.5 \\
\hline
\end{tabular}

Note: * Mean (standard deviation), ** 30 university students, *** Median; (Minimum maximum); BC Brazil Criterion 2013, Other = freelancer, photographer, bar tender, civil servant, sales.
People who tried alcohol at least once: 253 (90\%); were about 15.4 years old, when they first tried alcohol; $159(62,8 \%)$ said they were with friends when first tried it; 97 (38.3\%), were with relatives and $2(0.8 \%)$, were by their own (multiple response); 194 (76.7\%) still had alcoholic beverages; 30 (10.7\%) had physical or mental disease (Depression 3 (10\%), Obsessive-Compulsive Disorder $2(6.7 \%)$ and Diabetes Mellitus type I, $2(6.7 \%))$.

Tabela 2 - Comparison of the results of the Alcohol Use Disorders Identification Test (AUDIT) between nursing students in the $1^{\text {st }}$ and $3^{\text {rd }}$ stages of the research, Escola Paulista de Enfermagem-Universidade Federal de São Paulo, São Paulo State, Brazil, 2015

\begin{tabular}{|c|c|c|c|}
\hline \multirow{2}{*}{ AUDIT } & $1^{\text {st }}$ stage & $3^{\text {rd }}$ stage & \multirow{2}{*}{$p$ value } \\
\hline & $\mathrm{n}(\%)$ & n $(\%)$ & \\
\hline \multicolumn{4}{|l|}{ Result* } \\
\hline Low risk $<8$ & $216(79.4)$ & $230(84.6)$ & 0.059 \\
\hline Risky/harmful $\geq 8$ & $56(20.6)$ & $42(15.4)$ & \\
\hline \multicolumn{4}{|l|}{ Sum of Results* } \\
\hline Mean (DP) & $4.23(4.35)$ & $3.32(4.29)$ & $<0.0001$ \\
\hline \multicolumn{4}{|l|}{ Consumption frequency $*$} \\
\hline Never & $85(31.3)$ & $118(43.4)$ & $<0.0001$ \\
\hline Monthly or less & $75(27.6)$ & $70(25.7)$ & \\
\hline From 2 to 4 times/month & $94(34.6)$ & $76(27.9)$ & \\
\hline From 2 to 4 times/week & $18(6.6)$ & $8 \quad(2.9)$ & \\
\hline \multicolumn{4}{|l|}{ DATC** } \\
\hline 1 to 4 & $96(65.8)$ & $110(75.3)$ & 0.044 \\
\hline 5 to 7 or more & $50(34.2)$ & $36(24.7)$ & \\
\hline \multicolumn{4}{|l|}{ FI5DM** } \\
\hline Never & $43(29.5)$ & $47(32.2)$ & 0.3383 \\
\hline Less than once/month & $72(49.3)$ & $74(50.7)$ & \\
\hline Monthly & $25(17.1)$ & $20(13.7)$ & \\
\hline Weekly/every day & $6(4.1)$ & $5(3.4)$ & \\
\hline
\end{tabular}

Note: $A U D I T=$ The Alcohol Use Disorders Identification Test; $* 272$ university students; $* 146$ university students; DATC = Doses AmountTypically Consumed; FI5DM = Frequency they Ingest 5 Doses or More.

$\mathrm{BI}$ and the education material were evaluated as good for $176(64.7 \%)$ nursing university students and $179(65.8 \%)$ stated that the strategies contributed to a positive attitude towards alcohol consumption. There was a decrease in the alcohol consumption pattern between the stages (Table 3).

Table 4 shows the university students' QoL between the first and third stage of the study.

Table 5 shows that male, white, married, older, without a diagnosed disease, and not consuming alcohol students presented QoL scores substantially higher; evangelicals consumed less alcohol ( $p \leq 0.003)$, and less frequently $(p \leq 0.004)$ as the ones with no religion consumed more; female university students consumed less alcohol $(p \leq 0.015)$. The AUDIT's total score was higher among the white and single ones, and lower among evangelicals. Low risk consumption was substantially higher among married people ( $\mathrm{p} \leq 0.043$ ); and first grade students consumed less oftenly when compared to the fourth grade ones $(p \leq 0.009)$. There was a correlation ship between legal age's first consumption and AUDIT 
Table 3 - Comparison between the results of the Alcohol Use Disorders Identification Test (AUDIT) of the $1^{\text {st }}, 3^{\text {rd }}$ and $4^{\text {th }}$ stages of nursinguniversity students. Escola Paulista de Enfermagem -Universidade Federal de São Paulo, São PauloState, Brazil, 2016, $(\mathrm{n}=36)$

\begin{tabular}{|c|c|c|c|c|}
\hline \multirow{2}{*}{ AUDIT } & $1^{\mathrm{a}}$ stage & $3^{\mathrm{a}}$ stage & $4^{\mathrm{a}}$ stage & \multirow{2}{*}{$p$ value } \\
\hline & n (\%) & n (\%) & n (\%) & \\
\hline \multicolumn{5}{|l|}{ Results } \\
\hline Low risk $<8$ & $13(36.1)$ & $0(0)$ & $23(63.9)$ & 0.0001 \\
\hline Risky/harmful $\geq 8$ & $23(63.9)$ & $36(100)$ & $13(36.1)$ & \\
\hline \multicolumn{5}{|l|}{ Consumption frequency } \\
\hline Monthly or less & $8(22.2)$ & $7(19.4)$ & $11(30.6)$ & 0.1055 \\
\hline From 2 to 4 times/month & $19(52.8)$ & $23(63.9)$ & $23(63.9)$ & \\
\hline From 2 to 4 times/week & $9(25)$ & $6(16.7)$ & $2(5.6)$ & \\
\hline \multicolumn{5}{|l|}{ DATC } \\
\hline 1 to 4 & $16(44.4)$ & $14(38.9)$ & $24(66.7)$ & 0.0302 \\
\hline 5 to 7 or more & $20(55.6)$ & $22(61.1)$ & $12(33.3)$ & \\
\hline \multicolumn{5}{|l|}{ FI5DM } \\
\hline Never/ Less than once/month & $23(63.9)$ & $21(58.3)$ & $29(80.6)$ & 0.0418 \\
\hline Monthly/ Weekly & $13(36.1)$ & $15(41.7)$ & $7(19.4)$ & \\
\hline
\end{tabular}

Note: $D A T C=$ Doses amount tipically consumed, FI5DM = Frequency they ingest 5 doses or more.

Table 4 - Comparison of the average scores of the SF-36 domains of nursing students, among $1^{\text {st }}$ and $3^{\text {rd }}$ stage, Escola Paulista de Enfermagem -Universidade Federal de São Paulo, São Paulo State, Brazil, 2015 (n = 272)

\begin{tabular}{lccc}
\hline Domains & $\mathbf{1}^{\mathbf{a}}$ stage & $\mathbf{3}^{\mathbf{a}}$ stage & $\boldsymbol{p}$ value \\
\hline Functional Capacity & 90.37 & 88.65 & 0.0018 \\
Physical Aspect & 81.01 & 72.89 & 0.0001 \\
Pain & 71.94 & 71.65 & 0.8289 \\
General State of & 61.33 & 59.4 & 0.0144 \\
Health & 58 & 52.71 & 0.0001 \\
Vitality & 78.95 & 72.2 & 0.0023 \\
Social Aspects & 75.5 & 64.58 & 0.0002 \\
Emotional Aspects & 68.9 & 64.94 & 0.0002 \\
Mental Health & & & \\
\hline
\end{tabular}

score $\mathrm{p} \leq 0.0003, \mathrm{r}=-0.226$; low risk consumer had alcohol for the first time at the legal age $(p \leq 0.0001)$; the lower frequency and consumption have a correlation ship with the age of beginning $p \leq 0.0064$ and $p \leq 0.0001$.

\section{DISCUSSION}

Research conducted with nursing university students described there was a predominance of single, catholic and young women. As the skin color is self-reported and probably related to regional characteristics, we can find a predominance of white university students ${ }^{(4,9)}$. A similar study carried out in the northeast region of Brazil showed likeness between the variables, except in the predominance of white skin, as the brown skin prevailed ${ }^{(17)}$.

In this study, $90 \%$ of nursing university students had consumed alcohol at least once in life, higher percentage than that one related in the national survey about alcohol consumption, tobacco and other drugs among university students, conducted in 27 Brazilian state capitals, in which showed $86.2 \%{ }^{(3)}$. In Argentina, $75.3 \%$ of young people had already consumed alcohol(18) and also the $57.5 \%$ of Universidade Federal do Rio Grande do Sul health area university students ${ }^{(4)}$.

Table 5 - Sociodemographic and morbid variables of nursing undergraduates who presented significant correlation with The Alcohol Use Disorders Identification Test (AUDIT) and Medical scores Outcomes Studies 36-items short-form (SF36), Escola Paulista de Enfermagem, Universidade Federal de São Paulo, São Paulo State, Brazil, 2015 (N = 281$)$

\begin{tabular}{|c|c|c|c|c|c|c|c|c|c|}
\hline AUDIT & Gender & Skin Color & MS & Religion & Grade & Age & DD & FAAC & CCA \\
\hline $\mathrm{SR}$ & & 0.015 & 0.011 & 0.002 & & & & 0.0003 & \\
\hline Result & & & 0.043 & & & & & 0.0001 & \\
\hline IF & & & & 0.004 & 0.009 & & & 0.0064 & \\
\hline DATC* & 0.015 & & & & & & & 0.0001 & \\
\hline FI5DM* & & & & & & & & 0.0001 & \\
\hline \multicolumn{10}{|l|}{ SF 36} \\
\hline FC & 0.0259 & & & & & & 0.001 & & \\
\hline PA & & & 0.017 & & 0.001 & & & & \\
\hline Pain & & & & & 0.013 & & & & \\
\hline GSH & 0.0425 & & & & & & & & \\
\hline Vitality & 0.019 & 0.001 & & & & & & & \\
\hline
\end{tabular}


Table 3 (concluded)

\begin{tabular}{|c|c|c|c|c|c|c|c|c|c|}
\hline AUDIT & Gender & Skin Color & MS & Religion & Grade & Age & DD & FAAC & CCA \\
\hline SA & & 0.02 & 0.036 & & & 0.011 & & & \\
\hline EA & & 0.026 & & & & & & & \\
\hline $\mathrm{MH}$ & 0.0312 & & & & & & & & 0.03 \\
\hline
\end{tabular}

Note: *194 university students; SR = Sum of Results; FI=Ingestion Frequency; DATC = Doses Amount Typically Ingested; FI5DM = Frequency they Ingest 5 Doses or More; $F C=$ Functional Capacity; PA = Physical Aspect; GSH = Generate State of Health; SA = Social Aspects; EA = Emotional Aspects; MH = Mental Health; MS= Marital Status; $D D=$ Diagnosed Disease; FAAC = First Age of Alcohol Consumption; CCA = Currently Consuming Alcohol.

In this study, the average age of alcohol experimentation was 15.43 years ( 3 to 22 ); in Rio de Janeiro, $83.5 \%$ tried it before age 18 , of which $39.5 \%$ did so between 14 and 15 years $^{(19)}$. Among university students from Rio Grande do Sul in other health areas, $68 \%$ started drinking between 10 and $17^{(4)}$.

Brazilian male university students ingested alcohol in higher amount, frequency and doses per event than the female university students between 18 and 24 years old ${ }^{(3,20-21)}$. A research developed with adolescents in the United States of America showed that, alcohol consumption prevailed more among women and inferior age bracket, 12 and 17 years old, while in Europe countries, consumption was moderate. Another study pointed out the possibility of consumption at youth/adolescence to undermine development ${ }^{(22)}$.

The present study identified that the higher the age of onset of alcohol consumption, the lower the risk consumption, the frequency of intake and the number of doses consumed per event. Studies have shown that early ingestion puts the individual at greater risk of excessive consumption with consequent associated losses ${ }^{(18,23)}$.

Studies have shown that the main companies at the time of first use of alcoholic beverages are friends and relatives, as found among health students in southern Brazil, who reported being the first use with friends $(65.2 \%)$ and with relatives $(17.4 \%)^{(4)}$, while nursing students from the Southeast region reported $53.6 \%$ and $20.2 \%{ }^{(19)}$, respectively. The present study demonstrated a much higher percentage of first use $(38.3 \%)$ among the relatives, evidencing the influence of the family in the initiation of alcohol consumption.

Among the university students evaluated, 32.1\% had five or more doses, per event, while $26.2 \%$ of nursing university students of Universidade Federal de Salvador/Bahia had such amount ${ }^{(17)}$. A research conducted in 24 countries of Asia, Africa and Americas, with university students, verified a predominance of $11.3 \%$ in this pattern itself ${ }^{(24)}$.

Brazilian studies that identified the profile of alcohol consumption among university students using AUDIT revealed that $68 \%$ to $93.4 \%$ were low-risk drinkers and that $6.6 \%$ to $32 \%$, drinkers of risk/noxious/likely dependent, values which we can interpret as concerning, as well as the findings of the present study in the first stage, which were $79.4 \%$ and $20.6 \%$, respectively. However, after the $1^{\text {st }}$ and $2^{\text {nd }} \mathrm{BI}$, significantly reduced the number of drinkers for low risk $p \leq 0.059$ and $\leq 0.0001$, respectively, showing that the information/enlightenment interferes positively in the intake pattern and reduces the risk of negative evolution ${ }^{(20-21,25-26)}$.

Similar data in relation to the number of doses ingested, one to four doses, were casually identified among university students of this research and northeast region of Brazil(17). However, another study carried out in São Paulo with undergraduate students, using AUDIT before and after BI, showed that intervention generates meaningful changes, to a lesser extent, in the alcohol consumption pattern $(p=0.001)^{(9)}$. A systemic revision about $\mathrm{BI}$, in primary care, has also indicated a meaningful reduction in the excessive alcohol consumption, positively, impacting the users ${ }^{(8)}$. Another research has indicated that the awareness on consumption itself and its consequences favored the change in attitude and the decline of the pattern used ${ }^{(9)}$.

Brief Intervention, carried out with North-American consumers under risk of psychoactive substances needing primary care showed that, after three months of $\mathrm{BI}$, there was a considerable impact on the physical domain of psychoactive substances beginners' QoL ${ }^{(27)}$.

The average scores of QoL of nursing, Physiotherapy and Nutrition university students from Turkey was low, around 50, in all areas of SF-36 $6^{(28)}$. Physical education students from this same country, that consumed alcohol, showed meaningfully low score results when compared to the ones that never consumed it before ${ }^{(29)}$.

QoL has been shown to be lower among alcohol abusers of the most diverse ages. A study conducted in Australia with adults and elderly individuals who consumed alcoholic beverages showed a compromise in physical, psychological and social aspects ${ }^{(30)}$. A study conducted with Norwegians with a diagnosis of Substance Abuse Disorder, specifically polysubstances (heroin, methadone, cannabis, alcohol), showed that $75 \%$ evaluated QoL as very bad and bad ${ }^{(31)}$.

During this study there was a decrease in the QoL of nursing university students, according o them. An investigation carried out with post-graduate nursing students discloed that, during the course, they showed a decrease in QoL in several aspects due to characteristics and requirements of the job ${ }^{(32)}$. Many researches have been conducted with university students from different areas, such: university students from different areas, such: Pharmacy, Phonoaudiology, Medicine and Nursing. These courses stated that the physical ability domain obtained the best score average, about 84.5 , and the vitality was $47.8^{(33-34)}$. Besides the course characteristics, the female university students showed meaningfully low scores in the physical ability, vitality and mental health domains ${ }^{(34)}$.

Specifically, the mental health aspect of the QoL of nursing undergraduates, obtained through integrative review research, has been compromised during the course ${ }^{(35)}$. While the social aspects of the interviewees were the most satisfactory, and significantly higher in college students married and more than 20 years. Good performance in this area was related to 
satisfaction with the partner, support received from friends and relatives and sexual life ${ }^{(36)}$.

The social and emotional aspects scores and the university students with black skin vitality evaluated in this study were meaningful lower than in the university students with different skin colors. In the United States, people with black skin showed a worse QoL than the white skin ones, however, studies are limited to explain the real reasons for exist this difference in that country ${ }^{(37)}$. In Brazil, this research has observed that individuals that stated they had black or brown skin $(43.2 \%$ and $42.3 \%$, respectively) evaluated the QoL as being bad $^{(38)}$.

The Nursing course period may as well be a triggering factor for the university students QoL change. In the second year, in some curricular grids, the university student develops activities in the hospital that may cause anxiety, fear, anguish and conflicts $^{(39)}$. In the third year, the university student is better adapted to the university, to the hospital and to the teaching/ learning process and deals better with conflicting situations, which there may be stabilization or an upturn of QoL in some aspects and commitment from others related to the physical aspects due to cumulative activities of the course ${ }^{(40)}$.

Regarding the possible relation between alcohol consumption and alteration of QoL in the student population, a study showed that high school students had a negative perception of the psychological domain, especially in the group of risk/ harmful/likely dependent consumers. Interventions that emphasize physical activities and guidelines on consumptionrelated risks may improve adolescents' $\mathrm{QoL}^{(41)}$.

Studies have shown an association between the alteration of the various domains of QoL and the pattern of drinking among university students ${ }^{(29,42-43)}$. Physical, social and psychological consequences of alcohol consumption can negatively influence the consumer, family and society, and educational and preventive interventions are necessary.

A study conducted with university students in the health area who consumed alcohol concluded that their QoL was impaired by limitations or difficulties such as feeling sad, depressed, tired, with headache or migraine, and being emotionally shaken by everyday academic ${ }^{(44)}$.

\section{Study limitations}

Although the contributions of this study are relevant, they cannot be generalized, because it is a specific sample, university Nursing and public university; as well as possible inaccuracies in the answers of some university students.

\section{Contributions to the area of nursing, health or public policy}

We can consider as contributions of this study the understanding and confirmation of the impact of Brief Intervention as a stimulus technique to reduce the consumption pattern of alcohol, consequently of health prevention, specifically among university students of nursing, since they will be future professionals in the area of and as such, will need to work on health promotion and disease prevention for the general population. The results found on the consumption of risk and changes in the QoL of nursing undergraduate students can support new studies, as well as provide support for the nursing teaching and management practice.

\section{CONCLUSION}

The QoL of university students presented good scores, above 70, except in terms of vitality, general health and mental health; college students who consumed alcohol had a significantly lower mental health score; (FC, GSH, Vitality and $\mathrm{MH}$, and Vitality, SA and EA, respectively); married and aged over 20 years had significantly better social aspects and married couples also had significantly better physical aspects; after two Bls, there was a significant decrease in the consumption of risky/noxious/probable dependence, in the frequency of intake and in the number of doses consumed; the Bls were classified as good and collaborated to improve their attitude toward alcohol consumption.

Knowing the profile, the pattern of alcohol consumption, the QoL of university students and the role of the BI can subsidize internal actions in the university, as well as to increase the national and international literature on the subject to search for promotional and preventive measures related to the awareness of the consumption of alcohol by university students.

\section{REFERENCES}

1. United Nations. Office of Drugs and Crime. World Drug Report 2013 [Internet]. Vienna (Austria): United Nations; 2013 [cited 2017 May 20]. 151 p. Available from: https://www.unodc.org/unodc/secured/wdr/wdr2013/World_Drug_Report_2013.pdf

2. Silva ML, Rego FS, Roque NF, Valenti VE. Use of psychoactive substances in students at a public university. ABCS Health Sci [Internet]. 2014[cited 2017 May 20];39(3):160-6. Available from: https://www.portalnepas.org.br/abcshs/article/view/650/649

3. Brasil. Presidência da República. Secretaria Nacional de Políticas sobre Drogas. I Levantamento Nacional sobre o uso de álcool, tabaco e outras drogas entre universitários das 27 capitais brasileiras [Internet]. Brasília: SENAD; 2010 [cited 2017 May 20 ]. 282 p. Available from: http://www.grea.org.br/userfiles/GREA-ILevantamentoNacionalUniversitarios.pdf

4. Baumgarten LZ, Gomes VL, Fonseca AD. [Alcohol consumption among university students in the health area of Federal University of Rio Grande/RS: subsidy to the nursing]. Esc Anna Nery Rev Enferm[Internet]. 2012[cited 2017 May 20];16(3):530-5. Available from: http://www.scielo.br/pdf/ean/v16n3/15.pdf Portuguese

5. Tariq L, van den Berg M, Hoogenveen RT, van Baal PH. Cost-effectiveness of an opportunistic screening program and brief intervention for excessive alcohol use in primary care. PLoS One [Internet]. 2009 [cited 2017 May 20];4(5):e5696. Available from: https://www.ncbi.nlm.nih.gov/pmc/articles/PMC2682644/ 
6. Difulvio GT, Linowski SA, Mazziotti JS, Puleo E. Effectiveness of the Brief Alcohol and Screening Intervention for College Students (BASICS) program with a mandated population. J Am Coll Health [Internet]. 2012[cited 2017 May 20];60(4):269-80. Available from: https://dx.doi.org/10.1080/07448481.2011.599352

7. Humeniuk RE, Henry-Edwards S, Ali RL, Poznyak V, Monteiro M. The ASSIST-linked brief intervention for hazardous and harmful substance use: manual for use in primary care [Internet]. Geneva: World Health Organization; 2010 [cited 2017 Jun 10]. 46p. Available from: http://apps.who.int/iris/bitstream/10665/44321/1/9789241599399_eng.pdf

8. Pereira MO, Anginoni BM, Ferreira NC, Oliveira MA, Vargas D, Colvero LA. [Effectiveness of the brief intervention for the use of abusive alcohol in the primary: systematic review]. Rev Bras Enferm [Internet]. 2013[cited 2017 May 20];66(3):420-8. Available from: http://www.scielo.br/pdf/reben/v66n3/a18v66n3.pdf Portuguese.

9. Silva EC, Tucci AM. [Brief intervention to reduce alcohol consumption and its consequences in Brazilian university students]. Psicol Reflex Crit [Internet]. 2015[cited 2017 May 20];28(4):728-36. Available from: http://www.scielo.br/pdf/prc/v28n4/01027972-prc-28-04-00728.pdf Portuguese.

10. Jorngarden A, Wettergen L, von Essen L. Measuring health-related quality of life in adolescents and young adults: Swedish normative data for the SF-36 and the HADS, and the influence of age, gender, and method of administration. Health Qual Life Outcomes [Internet]. 2006[cited 2017 May 20];4:91. Available from: https://www.ncbi.nlm.nih.gov/pmc/articles/PMC1697805/ pdf/1477-7525-4-91.pdf

11. Associação Brasileira de Empresas de Pesquisa. Alterações na aplicação do Critério Brasil, válidas a partir de 01/01/2014 [Internet]. São Paulo: ABEP; 2012 [cited 2017 May 20]. 5 p. Available from: www.abep.org/Servicos/Download.aspx?id=01

12. Lima CT, Freire AC, Silva AP, Teixeira RM, Farrell M, Prince M. Concurrent and construct validity of the audit in an urban Brazilian sample. Alcohol Alcohol [Internet]. 2005[cited 2017 May 20];40(6):584-9. Available from: https://doi.org/10.1093/alcalc/agh202

13. Pillon SC, Santos MA, Gonçalves AM, Araújo KM. [Alcohol use and spirituality among nursing students]. Rev Esc Enferm USP [Internet]. 2011[cited 2017 May 20];45(1):98-105. Available from: http://www.scielo.br/pdf/reeusp/v45n1/en_14.pdf Portuguese.

14. Ciconelli RM, Ferraz MB, Santos W, Meinão I, Quaresma MR. Tradução para a língua portuguesa e validação do questionário genérico de avaliação de qualidade de vida SF-36 (Brasil SF-36). Rev Bras Reumatol. 1999;39(3):143-50.

15. Centro Brasileiro de Informações sobre Drogas Psicotrópicas. Bebidas alcoólicas (álcool etílico, etanol) [Internet]. São Paulo: Unifesp, Departamento de Psicobiologia; 2017[cited 2017 May 20]. Available from: http://www2.unifesp.br/dpsicobio/cebrid/ folhetos/alcool_htm

16. Brasil. Presidência da República, Secretaria Nacional de Políticas sobre Drogas. Drogas: cartilha álcool e jovens [Internet]. Brasília: Secretaria Nacional de Políticas sobre Drogas; 2010 [cited 2017 May 20]. 44 p. Available from: http://www.sgas.saude.ms.gov.br/ wp-content/uploads/sites/105/2016/07/cartilha_alcool_jovens.pdf

17. Pires CG, Mussi FC, Souza RC, Silva DO, Santos CA. Consumption of alcohol among nursing students. Acta Paul Enferm [Internet]. 2015 [cited 2017 May 20];28(4):301-7. Available from:http://www.scielo.br/pdf/ape/v28n4/en_1982-0194-ape-28-04-0301.pdf

18. Acosta LD, Fernandez AR, Pillon SC. [Social risk factors for alcohol use among adolescents and youth] Rev Latino-Am Enfermagem [Internet]. 2011[cited 2017 May 20];19(Spec No):771-81. Available from: http://www.scielo.br/pdf/rlae/v19nspe/15.pdf Spanish.

19. Tavares-Jomar R, Santos Silva E. Consumo de bebidas alcoólicas entre estudantes de enfermagem. Aquichan [Internet]. 2013[cited 2017 May 20];13(2):226-33. Available from: http://www.scielo.org.co/pdf/aqui/v13n2/v13n2a09.pdf

20. Carneiro AL, Rodrigues SB, Gherardi-Donato EC, Guimarães EA, Oliveira VC. [The pattern of alcohol consumption among college students of health areas]. Rev Enferm Cent O Min [Internet]. 2014[cited 2017 May 20];4(1):940-50. Available from: http://www. seer.ufsj.edu.br/index.php/recom/article/view/449/569 Portuguese.

21. Silva EC, Tucci AM. [Pattern of alcohol consumption in college students (freshmen) and gender differences]. Temas Psicol [Internet]. 2016[cited 2017 May 20];24(1):313-23. Available from: http://pepsic.bvsalud.org/pdf/tp/v24n1/v24n1a16.pdf Portuguese.

22. Cheng HG, Anthony JC. A new era for drinking? Epidemiological evidence on adolescent male-female differences in drinking incidence in the United States and Europe. Soc Psychiatry Psychiatr Epidemiol [Internet]. 2017[cited 2017 May 20];52(1):117-26. Available from: https://dx.doi.org/10.1007/s00127-016-1318-0

23. Vieira DL, Ribeiro M, Laranjeira R. Evidence of association between early alcohol use and risk of later problems. Rev Bras Psiquiatr [Internet]. 2007[cited 2017 May 20];29(3):222-7. Available from: http://www.scielo.br/pdf/rbp/v29n3/a06v29n3.pdf

24. Peltzer K, Pengpid S. Heavy drinking and social and health factors in university students from 24 low, middle income and emerging economy countries. Community Ment Health J [Internet]. 2016[cited 2017 May 20];52(2):239-44. Available from: https://dx.doi.org/10.1007/s10597-015-9925-x

25. Funai A, Pillon SC. [Use of alcoholic beverages and religious aspects among nursing students]. Rev Eletron Enferm [Internet]. 2011[cited 2017 May 20];13(1):24-9. Available from: http://www.fen.ufg.br/revista/v13/n1/v13n1a03.htm Portuguese.

26. Silva BP, Corradi-Webster CM, Donato EC, Hayashida M, Siqueira MM. [Common mental disorders, alcohol consumption and tobacco use, among nursing studentsata public university in the Western Brazilian Amazon]. SMAD Rev Eletron Saude Ment Alcool Drogas [Internet]. 2014[cited 2017 May 20];10(2):93-100. Available from: http://www.revistas.usp.br/smad/article/ view/98724/97287 Portuguese. 
27. Baumeister SE, Gelberg L, Leake BD, Yacenda-Murphy J, Vahidi M, Andersen RM. Effect of a primary care based brief intervention trial among risky drug users on health-related quality of life. Drug Alcohol Depend [Internet]. 2014[cited 2017 May 20];142:25461. Available from: https://www.ncbi.nlm.nih.gov/pmc/articles/PMC4127148/pdf/nihms-611373.pdf

28. Oztasan N, Ozyrek P, Kilic I. Factors associated with health-related quality of life among university students in Turkey. Mater Socio Med [Internet]. 2016[cited 2017 May 20];28(3):210-4. Available from: https://www.ncbi.nlm.nih.gov/pmc/articles/PMC4949046/ pdf/MSM-28-210.pdf

29. Emamvirdi R, HosseinzadehAsI N, Colakoglu FF. Health-related quality of life with regard to smoking, consumption of alcohol, and sports participation. Iran Red Crescent Med J [Internet]. 2016[cited 2017 May 20];18(7):e27919. Available from: https://www. ncbi.nlm.nih.gov/pmc/articles/PMC5022126/pdf/ircmj-18-07-27919.pdf

30. Lubman DI, Garfield JB, Manning V, Berends L, Best D, Mugavin JM et al. Characteristics of individuals presenting to treatment for primary alcohol problems versus other drug problems in the Australian patient pathways study. BMC Psychiatry [Internet]. 2016[cited 2017 May 20];16:250. Available from: https://www.ncbi.nlm.nih.gov/pmc/articles/PMC4950603/pdf/12888_2016_ Article_956.pdf

31. Muller AE, Skurtveit S, Clausen T. Many correlates of poor quality of life among substance users entering treatment are not addiction-specific. Health Qual Life Outcomes [Internet]. 2016[cited 2017 May 20];14:39. Available from: https://www.ncbi.nlm. nih.gov/pmc/articles/PMC4778354/pdf/12955_2016_Article_439.pdf

32. Freitas MA, Silva Jr OC, Machado DA. [Stress level and quality of life of resident nurses]. J Nurs UFPE [Internet]. 2016[cited 2017 May 20];10(2):623-30. Available from: http://www.revista.ufpe.br/revistaenfermagem/index.php/revista/article/view/7216/ pdf_9624 Portuguese.

33. Paro CA, Bittencourt ZZ. [Quality of Life of the Undergraduate Health Students]. Rev Bras Educ Med [Internet]. 2013 [cited 2017 May 20];37(3):365-75. Available from: http://dx.doi.org/10.1590/S0100-55022013000300009 Portuguese.

34. Souza IM, Paro HB, Morales RR, Pinto RM, Silva $\mathrm{CH}$. Health-related quality of life and depressive symptoms in undergraduate nursing students. Rev Latino-Am Enfermagem [Internet]. 2012[cited 2017 May 20];20(4):736-43. Available from: http://www. scielo.br/pdf/rlae/v20n4/14.pdf

35. Esperidião E, Barbosa JA, Silva NS, Munari DB. The mental health of nursing students: an integrative review of literature. SMAD Rev Eletron Saúde Ment Álcool Drogas [Internet]. 2013[cited 2017 May 20];9(3):144-53. Available from: http://www.revistas.usp. $\mathrm{br} / \mathrm{smad} / \mathrm{article/view/86745/89748}$

36. Moritz AR, Pereira EM, Borba KP, Clapis MJ, Gevert VG, Mantovani MF. Quality of life of undergraduate nursing students at a Brazilian public university. Invest Educ Enferm [Internet]. 2016[cited 2017 May 20];34(3):564-72. Available from: http://www. redalyc.org/articulo.oa? $\mathrm{id}=105247786015$

37. Pereira CC, Palta M, Mullahy J. Health domains and race in generic preference-based health-related quality of life instruments in the United States literature. Rev Bras Estud Popul [Internet]. 2010[cited 2017 May 20];27(2):425-37. Available from: http://www. scielo.br/pdf/rbepop/v27n2/11.pdf

38. Pavão AL, Werneck GL, Campos MR. [Self-rated health and the association with social and demographic factors, health behavior, and morbidity: a national health survey]. Cad Saúde Pública [Internet]. 2013[cited 2017 May 20];29(4):723-34. Available from: http://www.scielosp.org/pdf/csp/v29n4/10.pdf Portuguese.

39. Kawakame PM, Miyadahira AM. [Quality of life of undergraduate students in nursing]. Rev Esc Enferm USP [Internet]. 2005[cited 2017 May 20];39(2):164-72. Available from: http://www.scielo.br/pdf/reeusp/v39n2/06.pdf Portuguese.

40. Scherer ZA, Scherer EA, Carvalho AM. [Reflections on nursing teaching and students' first contact with the profession]. Rev Latino-Am Enfermagem [Internet].2006 [cited 2017 May 20];14(2):285-91. Available from: http://www.scielo.br/pdf/rlae/v14n2/ v14n2a20.pdf Portuguese.

41. Gordia AP, Silva RC, Quadros TM, Campos W. Behavioral and sociodemographic variables are associated with the psychological domain of adolescents' quality of life. Rev Paul Pediatr [Internet]. 2010[cited 2017 May 20];28(1):29-35. Available from: http:// www.scielo.br/pdf/rpp/v28n1/en_v28n1a06.pdf

42. Damasceno RO, Boery RN, Ribeiro IJ, Anjos KF, Santos VC, Boery EN. [Use of alcohol, tobacco and other drugs, and quality of life among college students]. Rev Baiana Enferm [Internet]. 2016 [cited 2017 May 20];30(3):1-10. Available from: https://portalseer. ufba.br/index.php/enfermagem/article/view/15533/pdf_65 Portuguese.

43. Manzatto L, Rocha TB, Vilela Jr GB, Lopes GM, Sousa JA. [Alcohol consumption and quality of life in college students]. Conexões [Internet]. 2011 [cited 2017 May 20];9(1):37-53. Available from: https://periodicos.sbu.unicamp.br/ojs/index.php/conexoes/ article/view/8637712/5403 Portuguese.

44. Faria JR, Ferreira MG, Lourenção LG, Tavares BB. [The alcohol abuse and the health university students quality of life]. Arq Ciênc Saúde [Internet]. 2014[cited 2017 May 20];21(2):82-8. Available from: http://repositorio-racs.famerp.br/racs_ol/vol-21-2/03/ ID\%20595\%2021(2)\%20Abr-jun\% 202014.pdf Portuguese. 